\title{
TERRESTRIAL MAMMALS OF A SHEEP-GRAZING PROPERTY ON BRUNY ISLAND, TASMANIA
}

\author{
by M.M. Driessen, K. Carlyon, R. Gales, N. Mooney, M. Pauza, S. Thurstans, M. Visoiu and P. Wise
}

\author{
(with two text-figures, three plates and seven tables)
}

\begin{abstract}
Driessen, M.M., Carlyon, K., Gales, R., Mooney, N., Pauza, M., Thurstans, S., Visoiu, M. \& Wise, P. 2011 (9:xii): Terrestrial mammals of a sheep-grazing property on Bruny Island, Tasmania. Papers and Proceedings of the Royal Society of Tasmania 145: 51-64. https://doi.org/10.26749/rstpp.145.51 ISSN 0080-4703. Department of Primary Industries, Parks, Water and Environment, PO Box 44, Hobart, Tasmania 7001, Australia (MMD*, KC, RG, NM, MP, ST, MV, PW) *Author for correspondence. Email: Michael.Driessen@dpipwe.tas.gov.au.

Land-based mammals were surveyed in a mosaic of dry sclerophyll forests and pasture on a sheep-grazing property on Bruny Island, Tasmania, using a range of methods in August 2010. This is the first mammal survey of a sheep-grazing property in Tasmania and the first large-scale survey of mammals on Bruny Island. Ten species were recorded comprising seven native and three introduced species. The Little Forest Bat, Vespadelus vulturnus, and the Black Rat, Rattus rattus, were recorded for the first time on Bruny Island, although both are probably long-term residents. No mammal species listed as rare or threatened under Tasmanian or Australian legislation were found on the property. Large numbers of Eastern Quolls, Dasyurus viverrinus, Brushtail Possums, Trichosurus vulpecula, Tasmanian Pademelons, Thylogale billardierii, and Bennetts Wallabies, Macropus rufogriseus, were recorded in a range of dry sclerophyll forests and in pasture. Longnosed Potoroos, Potorous tridactylus, were recorded widely on the property in native vegetation with relatively thick ground cover. Eastern Quoll capture rates were highest in pasture areas and in Eucalyptus ovata forest. Brushtail Possums, Long-nosed Potoroos, Tasmanian Pademelons and Bennetts Wallabies were virtually unrecorded from E. tenuiramis forest and woodlands. Given the level of survey effort and their potential to occur on the property it was remarkable that no Tasmanian Bettong, Bettongia gaimardi, Eastern Barred Bandicoot, Perameles gunnii, Southern Brown Bandicoot, Isoodon obesulus, or introduced House Mouse, Mus musculus, were recorded. We found that camera trapping was more cost-efficient than cage trapping for detecting the presence of mammals on "Murrayfield". Recommendations for ongoing management and monitoring of mammals are provided.
\end{abstract}

Key Words: mammals, islands, Eastern Quoll, Dasyurus viverrinus, management, fire, Bruny Island, Tasmania, sheep farm, camera trapping.

\section{INTRODUCTION}

"Murrayfield" is a 4097-ha property on the northern part of Bruny Island, Tasmania, owned by the Indigenous Land Corporation and managed in partnership with the Weetapoonah Aboriginal Corporation. One of the aims for management of the property is to balance the demands of running an established sheep and fine merino wool business with protecting cultural and environmental values (ILC 2009). A native vegetation management plan has been prepared for the property (Sherriff \& Magnus 2005). A bird survey (Lloyd 2009) and a preliminary investigation of the geology, geomorphology and landscape evolution of the property have also been completed (Pemberton 2004). At the request of the Weetapoonah Aboriginal Corporation, we undertook a terrestrial mammal survey of the Murrayfield Station. There has been no previous large-scale survey aimed at assessing a range of mammal species on Bruny Island. The only previous study was by Hird (2000) who surveyed Dennes Hill using cage traps and recorded eight species (see below). Furthermore, there has been no previous mammal survey of grazing properties in Tasmania. Previous surveys, targeting a broad range of mammalian taxa, have been in native vegetation communities and mostly in wet forests and heathlands of western Tasmania (Green 1977, 1979, Hocking \& Guiler 1983, Green 1984, Taylor et al. 1985, Slater 1992, Driessen et al. 1995, 2002, Driessen \& Jarman 2010). The aims of this survey were: (1) to establish baseline data on mammal populations and to provide recommendations for their ongoing management; and (2) to compare mammal populations between the main vegetation communities on the property.

\section{Existing mammal records for Bruny Island}

Before undertaking the survey, we summarised existing information on terrestrial mammals for Bruny Island, obtaining records from published literature and from records held on the Natural Values Atlas-a database of species location records managed by the Tasmanian Department of Primary Industries, Parks, Water and Environment (www. naturalvaluesatlas.tas.gov.au). Records are contributed to this database from a variety of sources including expert and public observations, permit reports and publications.

Woinarski (1985) reported Gould's Wattled Bat, Chalinolobus gouldii (Gray, 1841) roosting in a stump on northern Bruny Island. Ziegeler (1971) observed a Shortbeaked Echidna, Tachyglossus aculeatus (Shaw, 1792) at Adventure Bay. Hird (2000) surveyed Dennes Hill Reserve in 1996 and recorded the presence of eight mammal species (table 1). He also reported an unpublished observation of a Lesser Long-eared Bat, Nyctophilus geoffroyi Leach, 1821. In a review of the distributions of mammals in Tasmania, including offshore islands, Rounsevell et al. (1991) mapped the distribution of native terrestrial mammals using records from the TASPAWS Biological Records Scheme (which morphed into the Natural Values Atlas). They documented 13 mammal species on Bruny Island (table 1). Cochran (2003) mentioned the occurrence of Little Pygmy Possums, Cercartetus lepidus (Thomas, 1888) in her compilation of information on threatened species on Bruny Island, and Hird (2009) recorded both Little Pygmy Possums and Eastern Pygmy Possums, Cercartetus nanus (Geoffroy \& Desmarest, 1817) in artificial nest boxes adjacent to the airstrip on northern Bruny Island. Driessen et al. (2011) 
TABLE 1

Existing records of native and introduced terrestrial mammals on Bruny Island

\begin{tabular}{|c|c|c|c|c|}
\hline Species & & Northern Bruny & Southern Bruny & Source \\
\hline \multicolumn{5}{|l|}{ Native Mammals } \\
\hline Platypus & Omithorbynchus anatinus & - & + & 1,2 \\
\hline Short-beaked Echidna & Tachyglossus aculeatus & + & + & 1,2 \\
\hline Spotted-tailed Quoll & Dasyurus maculatus & - & - & \\
\hline Eastern Quoll & Dasyurus viverrinus & + & + & $1,2,3$ \\
\hline Tasmanian Devil & Sarcophilus harrisii & - & - & \\
\hline Swamp Antechinus & Antechinus minimus & - & + & 1,2 \\
\hline Dusky Antechinus & Antechinus swainsonii & - & + & 1,2 \\
\hline White-footed Dunnart & Sminthopsis leucopus & - & + & 1,2 \\
\hline Southern Brown Bandicoot & Isoodon obesulus & - & + & 1 \\
\hline Eastern Barred Bandicoot & Perameles gunnii & - & + & 2 \\
\hline Smooth-nosed Wombat & Vombatus ursinus & - & - & \\
\hline Ringtail Possum & Pseudocheirus peregrinus & + & - & 3 \\
\hline Sugar Glider & Petaurus breviceps & - & - & \\
\hline Brushtail Possum & Trichosurus vulpeculda & + & + & $1,2,3$ \\
\hline Little Pygmy Possum & Cercatetus lepidus & + & + & $1,4,5$ \\
\hline Eastern Pygmy Possum & Cercatetus nanus & + & + & 5 \\
\hline Long-nosed Potoroo & Potorous tridactylus & + & + & $1,2,3$ \\
\hline Tasmanian Bettong & Bettongia gaimardi & + & + & 1,2 \\
\hline Tasmanian Pademelon & Thylogale billardierii & + & + & $1,2,3$ \\
\hline Bennetts Wallaby & Macropus rufogriseus & + & + & 2,3 \\
\hline Forester Kangaroo & Macropus giganteus & - & - & \\
\hline Water Rat & Hydromys chrysogaster & + & - & 3 \\
\hline Long-tailed Mouse & Pseudomys higginsi & - & + & 1 \\
\hline New Holland Mouse & Pseudomys novaehollandiae & - & - & \\
\hline Broad-toothed Mouse & Mastacomys fuscus & - & - & \\
\hline Swamp Rat & Rattus lutreolus & - & + & 2 \\
\hline Goulds Wattled Bat & Chalinolobus gouldii & + & - & 7 \\
\hline Chocolate Wattled Bat & Chalinolobus morio & - & - & \\
\hline Large Forest Bat & Vespadelus darlingtoni & - & - & \\
\hline Southern Forest Bat & Vespadelus regulus & - & - & \\
\hline Little Forest Bat & Vespadelus vulturnus & - & - & \\
\hline Tasmanian Pipistrelle & Falsistrellus tasmaniensis & - & - & \\
\hline Lesser Long-eared Bat & Nyctopbilus geoffroyi & - & + & 3 \\
\hline Tasmanian Long-eared Bat & Nyctophilus sherrini & - & - & \\
\hline Total & & 12 & 18 & \\
\hline \multicolumn{5}{|l|}{ Introduced Maummals } \\
\hline Goat & Capra hircus & - & + & 2 \\
\hline Cat & Felis catus & - & + & 2 \\
\hline House Mouse & Mus musculus & - & + & 2 \\
\hline Rabbit & Oryctolagus cuniculus & + & - & 2 \\
\hline Fox & Vulpes vulpes & + & - & 6 \\
\hline Total & & 2 & 3 & \\
\hline
\end{tabular}

1 = Rounsevell et al. (1991), 2 = Natural Values Atlas, 3 = Hird (2002), 4 = Cochran (2003),

$5=($ Hird 2009), $6=$ DPIPWE (2011), $7=$ Woinarski (1985) ' - ' = not recorded 
reviewed the status and conservation of bats in Tasmania but provided no additional records for the island.

Twenty-one native terrestrial mammal species $(59 \%$ of State total) have been recorded from Bruny Island (table 1). Of the remaining 13 Tasmanian species that have not been recorded on the island, seven are unlikely to be found there. They are the Broad-toothed Mouse, Mastacomys fuscus Thomas, 1882, New Holland Mouse, Pseudomys novaehollandiae (Waterhouse, 1843) (unsuitable habitat and both species not known from southeast Tasmania), Tasmanian Devil, Sarcophilus harrisii (Boitard, 1841), Spotted-tailed Quoll, Dasyurus maculatus (Kerr, 1792), Smooth-nosed Wombat, Vombatus ursinus (Shaw, 1800), Eastern Grey Kangaroo, Macropus giganteus Shaw, 1790 (conspicuous species that have not been recorded on the island, at least in recent times) and the Sugar Glider, Petaurus breviceps Waterhouse, 1839.

Although the Sugar Glider is known. from the adjacent Tasmanian mainland, it is unlikely to occur on the island if, as has been suggested by Green (1973), it was introduced to Tasmania in colonial times. There are observations of possible Tasmanian Devils occurring on southern Bruny Island contained in meeting notes of the Royal Society of Tasmania in 1871 (K. Medlock, Tasmanian Museum and Art Gallery and D. Pemberton, Department of Primary Industries, Parks, Water and Environment, unpublished data); however, there is no other evidence of devils occurring on the island. The Natural Values Atlas contains a 1996 record of a Spotted-tailed Quoll near Apollo Bay on northern Bruny Island and Hird (2000 p.11) mentioned that a resident of northern Bruny Island "had trapped a spottedtailed quoll near Dennes Hill in a possum cage". It is not clear if these two records are of the same incident. Menna Jones (pers. comm., University of Tasmania), who received the Natural Values Atlas record by phone from a member of the public, could not confirm the identification. Given the lack of any other evidence for Spotted-tailed Quolls on the island, we assume that this species does not occur there. The remaining six species (all bats) have a high probability of occurring on the island due to suitable habitat there and known populations on the adjacent Tasmanian mainland (Driessen et al. 2011).

The northern and southern parts of Bruny Island are separated by a narrow isthmus, called The Neck, which is approximately $2 \mathrm{~km}$ long and $100 \mathrm{~m}$ wide at its narrowest part. A greater number of terrestrial mammal species has been recorded on southern Bruny Island (18 species) than on northern Bruny Island (12 species) (table 1). Hird (2000) questioned whether the Eastern Barred Bandicoot, Perameles gunnii Gray, 1838 has been recorded from northern Bruny Island as reported by Rounsevell et al. (1991) because the scale of mapping used in the latter paper was not sufficient to delineate between Bruny Island and the Tasmanian mainland. In support of Hird (2000) we found no records of the Eastern Barred Bandicoot for northern Bruny Island on the Natural Values Atlas.

The difference in number of mammal species between northern and southern Bruny Island is most likely because of vegetation differences. Southern Bruny Island contains wet forests and coastal heathlands which are virtually absent from northern Bruny Island, which would explain the occurrence on southern Bruny Island of the Long-tailed Mouse, Pseudomys higginsi (Trouessart, 1897), Swamp Rat, Rattus lutreolus (Gray, 1841), Dusky Antechinus, Antechinus swainsonii (Waterhouse, 1840), and Swamp Antechinus,
Antechinus minimus (Geoffroy, 1803). The Neck, which is dominated by road, sand, mud and sparse coastal vegetation, may act (or have acted since the last sea level rise) as a barricr to mammal dispersal between the two parts of the island.

Seven species (Tasmanian Bettong, Long-tailed Mouse, Swamp Rat, Swamp Antechinus, Dusky Antechinus, Whitefooted Dunnart Sminthopsis leucopus (Grey, 1842), and Platypus, Ornithorhynchus anatinus (Shaw, 1799), were last recorded on the island in the 1970s and 1980s.

In addition to native terrestrial mammals, five species of introduced mammals have been recorded living wild on Bruny Island (table 1). One Fox scat, Vulpes vulpes Linnaeus, 1758, confirmed by DNA testing, was found on northern Bruny Island in May 2010 (DPIPWE 2011). Follow-up surveys using scat-detector dogs were undertaken but the scats collected tested negative for Fox (R. Gaffney, Fox Eradication Branch, pers. comm.). Other introduced mammal species expected to occur on the island include Black Rats, Rattus rattus (Linnaeus, 1758), and Brown Rats, Rattus norvegicus (Berkenhout, 1769).

Bruny Island is the fourth largest offshore island in Tasmania (36 200 ha) and has the highest number of native terrestrial mammal species of any Tasmanian island (19 species excluding bats, which have been poorly surveyed). The three larger islands-Flinders Island (133 300 ha, 13 species), King Island (110 160 ha, 12 species) and Cape Barren Island (47 840 ha, six species) - all contain fewer species (based on number of species at time of European settlement reported by Hope (1972) and Rounsevell et al. (1991)). Bruny Island is the only island in Tasmania known to have naturally occurring populations of Eastern Quolls, Eastern Barred Bandicoots, Tasmanian Bettongs, Long-tailed Mice, Dusky Antechinus and Little Pygmy Possums. The greater number of species on Bruny Island is likely to be a result of a range of wet and dry habitats present on the island and perhaps close proximity (closest point $=2 \mathrm{~km}$ ) to the Tasmanian mainland with a relatively shallow intervening channel (shallowest depth $=11 \mathrm{~m}$ ). In comparison, Cape Barren Island, which is the closest of the three larger islands, is over $30 \mathrm{~km}$ from the Tasmanian mainland with the shallowest connecting depth approximately $24 \mathrm{~m}$. Hence, Bruny Island would have been connected to the Tasmanian mainland more frequently and for longer periods than the other three large islands, increasing the likelihood of mammal colonisation from the Tasmanian mainland.

\section{METHODS}

\section{Site description}

A comprehensive description of the property is given in the Murrayficld Native Vegetation Management Plan (Sherriff \& Magnus 2005) and is summarised here. "Murrayfield" is 4097 ha in size and covers about half of Bruny Island north of The Neck (pl. 1). Approximately half of the total area of the property is native vegetation, most of which is in good condition, and the remainder is pasture. The native vegetation is predominantly dry sclerophyll vegetation types with several patches of mixed wet sclerophyll vegetation in gullies. Images of two of the main native vegetation types on the property are shown in pls 2 and 3. Approximately 12 000 sheep are run on the property. Adjoining properties are mostly private farming land or rural residential. Bruny Island Neck Game Reserve borders the southern boundary of the 


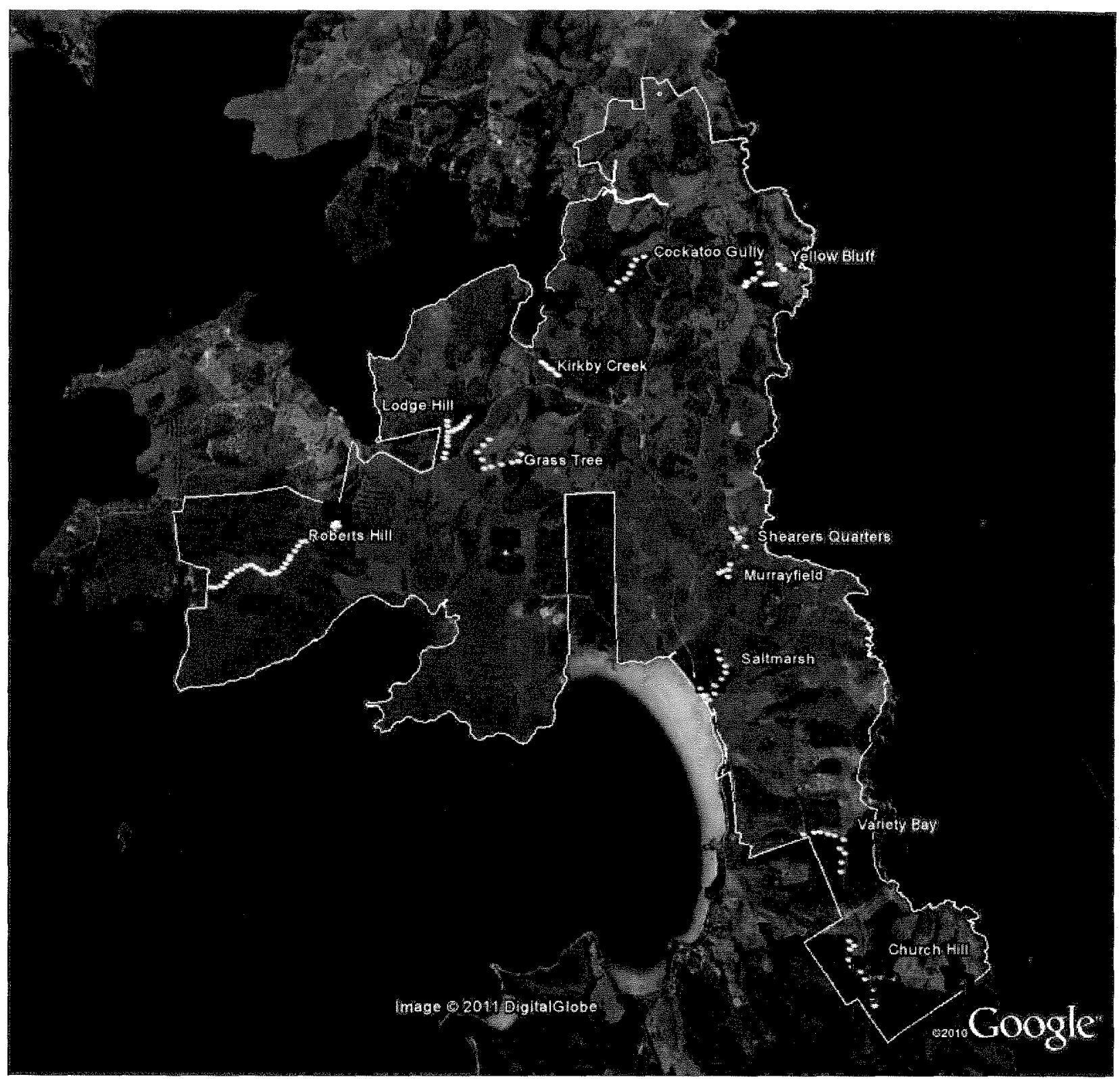

PLATE 1

Location of "Murrayfeld" and trap stations.

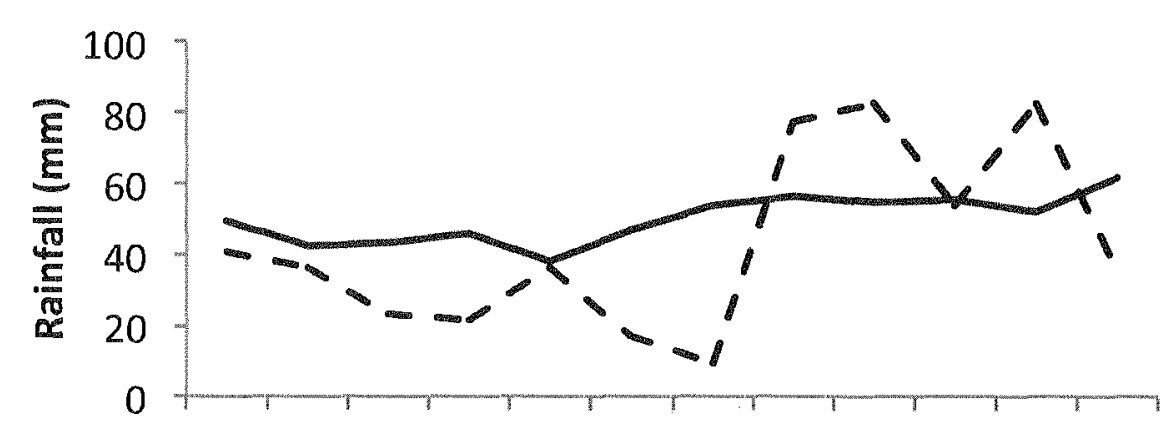

Jan Feb Mar Apr May Jun Jul Aug Sep Oct Nov Dec

FIG. 1 - Mean monthly rainfall (solid line, 1984-2010) and monthly rainfall for 2010 (dashed line). Source: Bureau of Meteorology, Bull Bay Weather Station. 
property. Wallabies and possums on the property are subject to regular culling under licence for crop protection purposes.

Mean annual rainfall for northern Bruny Island is 673 $\mathrm{mm}$ (based on Bureau of Meteorology records from Bull Bay for the period 1984-2010). Highest mean monthly rainfalls occur from July to December with December receiving the highest total on average (fig. 1 ). Mean monthly maximum temperatures range from $21.2^{\circ} \mathrm{C}$ in January and February to $12.5^{\circ} \mathrm{C}$ in July. Mean monthly minimum temperatures range from $12.6^{\circ} \mathrm{C}$ in February to $5.8^{\circ} \mathrm{C}$ in July. For the eight months prior to our survey in August 2010 (December 2009--July 2010) rainfall was 60\% below the long-term average for that same period of months (fig. 1). Mean minimum and monthly temperatures during this eight month period were higher than the long-term mean with some mean monthly values up to a degree warmer.

\section{Mammal survey techniques}

The survey was conducted during August 2010 using a range of techniques. To gain a full picture of the abundance and distribution of mammals in relation to "Murrayfield"'s vegetation types and land uses, we aimed to survey mammals in all major vegetation types on the property and distributed our sampling effort to obtain a good spatial coverage of the property. Sites were biased towards locations with vehicle access.

\section{Live Trap and Release}

Mammal trapping occurred over three nights (23-26 August), using cage traps ( $25 \times 25 \times 56 \mathrm{~cm}$, Mascot Wireworks) and aluminium box traps $(11 \times 11 \times 33 \mathrm{~cm}$, Elliott Scientific). At most locations one cage and one box trap were set every $100 \mathrm{~m}$ along a transect, which typically followed a track, with traps placed $10-30 \mathrm{~m}$ into the trackside vegetation. The exceptions to this pattern occurred at Roberts Hill, Lodge Hill and Kirkby Creek. At Roberts Hill a box trap alternated with a box/cage trap pair every $50 \mathrm{~m}$ for $1.4 \mathrm{~km}$ and then six box traps were set every $50 \mathrm{~m}$ in at the end of this line. At Lodge Hill, a box trap alternated with a box/cage trap pair every $50 \mathrm{~m}$ along the track to the top of the hill. A further six cage/box trap pair was set every $50 \mathrm{~m}$ around the side of Lodge Hill. At Kirkby Creek, six cage/box trap pairs were set every $50 \mathrm{~m}$ along the gully. In addition, at Church Hill, an extra four box traps were set along the dry creekline for three nights. Trap locations are shown in pl. 1 and the numbers of traps set at each location is given in table 2. Cage traps were baited with peanut butter sandwiches and were covered with plastic or hessian bags to protect trapped animals from the elements. Box traps were baited with peanut butter and rolled oats balls and covered with plastic bags. Dacron was placed in all traps for insulation. A harp trap was set to capture bats on the vehicle tracks at the Saltmarsh location (3 nights) and the Cockatoo Gully location (2 nights) and checked each evening and morning. Only two harp traps were available and we chose locations that we assumed would have a good chance of catching bats-a track with dense vegetation either side and with some over-hanging branches. Most animals captured had the following recorded: species, sex, head length, hind foot length and reproductive status. The forearms of bats were measured to aid species identification. A small hair clip was taken to mark each animal caught except bats, Short-beaked Echidnas and Brushtail Possums, Trichosurus vulpecula (Kerr, 1792). Echidnas and Brushtail Possums were not handled. Each trap location was assigned to a TASVEG vegetation group based on TASVEG mapping and ground-truthing (table 2).

\section{Camera Traps}

Ten remote cameras (Digital Eye, Pix Controller Inc.) were set up on 20 August 2010 and retrieved 17 days later on 6 September 2010. The traps were deployed in areas with road access and with the aim of getting broad spatial and vegetation coverage. Two cameras were placed on Church Hill to survey the dry forest on the ridge and the wet forest in the gully. The cameras were placed on a small tree trunk. $75 \mathrm{~cm}$ above the ground. The attractant-comprising peanut butter, rolled oats and tuna oil-was placed in a PVC capsule $1.5 \mathrm{~m}$ from the camera. The capsule, which had a conical lid with slits, was partially buried in the ground and anchored with a tent peg. The cameras were set for continuous recording with a 30-second delay between photos. The passive infra-red sensor was triggered by movement or heat. Locations of camcra traps are shown in pl. 1. We provide information on the number of images captured for each mammal species for each camera. This information should be used with caution as we do know how many individual animals were recorded and hence may not be indicative of relative abundance.

\section{Spotlighting}

Spotlighting was undertaken from a vehicle each night (3 nights) along the main tracks on the station: Variety Bay (start: $531600 \mathrm{E}, 5217300 \mathrm{~N}$; finish: $534400 \mathrm{E}, 5216000 \mathrm{~N}$ ), grass tree track $(529300 \mathrm{E}, 5220300 \mathrm{~N} ; 528938 \mathrm{E}, 5223000 \mathrm{~N})$, Yellow Bluff ( $530500 \mathrm{E}, 5223500 \mathrm{~N} ; 531400 \mathrm{E}, 5223900 \mathrm{~N})$, Lodge Hill $(527800 \mathrm{E}, 5222000 \mathrm{~N} ; 528100 \mathrm{E}, 5223000 \mathrm{~N})$, Trumpeter Bay Road (531700E 5220800N; 532900E, $5217200 \mathrm{~N})$ and shortcut paddock $(531300 \mathrm{E}, 5220900 \mathrm{~N}$, $530700 \mathrm{E} ; 5220000 \mathrm{~N})$. Spotlighting was repeated on Trumpeter Bay Road and grass tree track to gauge nightly variation in the spotlight counts. The passenger and driver each used a 100-W halogen spotlight to cover their respective sides of the track, taking care not to double count animals crossing the track in front of the vehicle. We compared our spotlight counts of mammal species with annual averages from the statewide spotlight surveys for 1985-1990 (Driessen \& Hocking 1992). The statewide spotlight surveys cover a wide range of vegetation types and no comparisons of mammal counts between vegetation types has been published. Thus the average spotlight counts presented by Driessen \& Hocking (1992) include transects that traverse vegetation types that may not support some mammal species.

\section{Mammal sign}

Any signs of mammals such as scats, skulls, diggings and nests were noted opportunistically.

\section{RESULTS AND DISCUSSION}

Ten terrestrial mammal species were recorded on "Murrayfield" of which seven are native to Tasmania and three are introduced species (excluding domesticated species) (table 3). The Little Forest Bat, Vespadelus vulturnus (Thomas, 1914), and the Back Rat have not been recorded previously from the island although no doubt local residents would be aware of Black Rats. The Eastern Quoll and the Tasmanian Pademelon, Thylogale billardierii (Desmarest, 1822) are now restricted to Tasmania; Australian mainland populations became extinct in the twentieth century (Johnson \& Rose 2008, 
TABLE 2

Number of trap nights by vegetation type

\begin{tabular}{|c|c|c|c|c|c|c|c|c|c|c|}
\hline Location & 'Trap'Тype & DAC & DGL & DOB & DOV & DPU & DTO & FAG & WGL & Total \\
\hline \multirow[t]{2}{*}{ Church Hill } & $\mathrm{C}$ & & & 6 & & & 24 & & & 30 \\
\hline & B & & & 18 & & & 24 & & & 42 \\
\hline \multirow[t]{2}{*}{ Cockatoo Gully } & $\mathrm{C}$ & & & & 8 & 6 & & & & 14 \\
\hline & B & & & & 8 & 4 & & & & 12 \\
\hline \multirow[t]{2}{*}{ Grass Tree } & $\mathrm{C}$ & 15 & & & & & & 15 & & 30 \\
\hline & B & 15 & & & & & & 15 & & 30 \\
\hline \multirow[t]{2}{*}{ Kirkby Creek } & C & & 18 & & & & & & & 18 \\
\hline & B & & 18 & & & & & & & 18 \\
\hline \multirow[t]{2}{*}{ Lodge Hill } & $\mathrm{C}$ & & & & & 30 & & & & 30 \\
\hline & B & & & & & 42 & & & & 42 \\
\hline Murrayfield & $\mathrm{C}$ & & & 5 & & & & & & 5 \\
\hline \multirow[t]{2}{*}{ Roberts Hill } & $\mathrm{C}$ & & & & & 45 & & & & 45 \\
\hline & B & & & & & 99 & & & 6 & 105 \\
\hline \multirow[t]{2}{*}{ Saltmarsh } & $\mathrm{C}$ & 30 & & & & & & & & 30 \\
\hline & B & 30 & & & & & & & & 30 \\
\hline Shearing Quarters & $\mathrm{C}$ & & & & & & & 5 & & 5 \\
\hline \multirow[t]{2}{*}{ Variety Bay } & $\mathrm{C}$ & & & & & & 30 & & & 30 \\
\hline & B & & & & & & 30 & & & 30 \\
\hline \multirow[t]{2}{*}{ Yellow Bluff } & C & & & & & 20 & & & & 20 \\
\hline & B & & & & & 20 & & & & 20 \\
\hline \multirow[t]{2}{*}{ Total } & C & 45 & 18 & 11 & 8 & 101 & 54 & 20 & 0 & 257 \\
\hline & B & 45 & 18 & 18 & 8 & 165 & 54 & 15 & 6 & 329 \\
\hline
\end{tabular}

$\mathrm{C}=$ cage trap and $\mathrm{B}=$ Box trap. $\mathrm{DAC}=$ Eucalyptus amygdalina coastal forest and woodland, $\mathrm{DGL}=E$. globulus dry forest and woodland, $\mathrm{DOB}=$ E. obilqua dry forest, $\mathrm{DOV}=E$. ovata forest and woodland, $\mathrm{DPU}=$ En pulchella forest and woodland, $\mathrm{DTO}=$ E. tenuiramis forest and woodland on sediments, FAG $=$ agricultural land, WGL $=$ E. globulus wet forest.

TABLE 3

List of mammal species recorded on "Murrayfield"

\begin{tabular}{llcl}
\hline Species & & Status & \multicolumn{1}{c}{ Method of Detection } \\
\hline Short-beaked Echidna & Tachyglossus aculeatus & $\mathrm{N}$ & L, C, O, D \\
Eastern Quoll & Dasyurus viverrinus & $\mathrm{Ne}$ & L, C, Osp, T, Sc \\
Brushtail Possum & Trichosurus vulpecula & $\mathrm{N}$ & L, C, Osp, Sc \\
Long-nosed Potoroo & Potorous tridactylus & $\mathrm{N}$ & L, C, Osp, T, D \\
Tasmanian Pademelon & Thylogale billardierii & $\mathrm{Ne}$ & C, Osp, Sc \\
Bennetts Wallaby & Macropus rufogriseus & $\mathrm{N}$ & C, Osp, Sc \\
Little Forest Bat & Vespadelus vulturnus & $\mathrm{N}$ & L \\
Domestic Cat & Felis catus & $\mathrm{I}$ & L \\
Black Rat & Rattus rattus & $\mathrm{I}$ & L, C \\
European Rabbit & Oryctolagus cuniculus & $\mathrm{I}$ & Osp, Sc \\
\hline
\end{tabular}

$\mathrm{N}=$ native species, $\mathrm{e}=$ endemic species, $\mathrm{I}=$ introduced species, $\mathrm{C}=$ camera trap, $\mathrm{D}=\mathrm{digging}, \mathrm{L}=\mathrm{live}$ trap and release, $\mathrm{O}=\mathrm{observed}$, Osp=observed by spotlighting, $\mathrm{Sc}=$ scat, $\mathrm{T}=$ tracks. 
Jones 2008). Currently three species of extant, terrestrial mammal are listed on the Tasmanian Threatened Species Protection Act 1995 (New Holland Mouse, Tasmanian Devil and Spotted-tailed Quoll) and these are unlikely to occur on the island (see above). The Eastern Barred Bandicoot is listed on the Australian Environment Protection and Biodiversity Conservation Act 1999. It has been previously recorded on Bruny Island and has the potential to occur on the property but was not recorded during our survey (see below).

\section{Monotremes}

\section{Short-beaked Echidna}

Four Short-beaked Echidnas were recorded in four different vegetation types: Eucalyptuspulchella Desf. forest, E. tenuiramis Miq. forest, E. amygdalina Labill. coastal forest and pasture (tables 4-7). Diggings made by echidnas were observed widely throughout the property. Similarly, Hird (2000) found that echidna diggings were common on Dennes Hill and around the Denne's farm.

\section{Marsupials}

\section{Eastern Quoll}

Only one carnivorous marsupial was recorded on "Murrayfield", the Eastern Quoll. This species was commonly and widely recorded on the property using cage traps, camera traps and spotlighting (tables $4-7$ ). The capture rate was 26 individuals caught per 100 cage trap nights which is considerably higher than rates reported in rainforest, wet forest, heathland and alpine vegetation elsewhere in Tasmania where less than one Eastern Quoll was caught per 100 cage trap nights (Hocking \& Guiler 1983, Taylor et al. 1985, Driessen et al. 1995). Our capture rates were also higher than those of Hird (2000) who caught one Eastern Quoll in 75 trap nights on Dennes Hill in 1996 in habitat similar to that found on "Murrayfield", suggesting that quoll numbers may have increased since that time. Our capture rates were similar to those found in E. tenuiramis forest and woodland in southeast Tasmania two years after a cool fire (Driessen et al. 1991). However, the captures rates recorded by Driessen etal. (1991) declined significantly four years later and they suggested that this may be associated with decreases in invertebrate prey. Eastern Quolls were captured in all major vegetation types surveyed but there was a significant difference in capture rates between vegetation types $\left(\chi^{2}=14.625, \mathrm{df}=6, \mathrm{p}<0.026\right)$ with a higher capture rate in E.ovata Labill. forest and in pasture areas than in other vegetation types (fig. 2). Eastern Quolls reach their highest densities where pasture is adjacent to eucalypt forest (Jones \& Rose 2001) probably because of the abundant invertebrate food resource in pastures adjacent to native vegetation cover. The high captures of Eastern Quolls in E.ovata Labill. forest should be regarded with caution as our survey effort in this vegetation type was limited (8 trap nights). However, E.ovata forests are associated with drainage flats and fertile soils (Harris \& Kitchener 2005) and may provide good invertebrate foraging areas for quolls.

Eastern Quolls were recorded on most spotlight transects at an overall rate of 10 quolls per $10 \mathrm{~km}$. This rate is much greater than the maximum average rate $(0.5$ quolls per 10 $\mathrm{km}$ ) recorded on $13010-\mathrm{km}$ transects during the annual statewide spotlight survey program between 1985 and 1990 (Driessen \& Hocking 1992), and supports the view that quoll numbers were high during the survey of "Murrayfield".
We do not know why Eastern Quoll abundance was high during our survey.

A total of 68 different Eastern Quolls were caught and measured during the survey which allowed further investigation of the characteristics of the population. One female with pouch young was caught in a box trap and all other animals were caught in cage traps. The sex ratio of 38 males to 30 females did not differ significantly from parity $\left(\chi^{2}=0.94, \mathrm{df}=1, \mathrm{p}>0.5\right)$. The mean body weights ( \pm s.e. $)$ of male and female quolls were $1061 \pm 33.8 \mathrm{~g}$ (range: $700-$ $1620, \mathrm{n}=38$ ) and $783 \pm 24.5 \mathrm{~g}$ (range: $500-1120 \mathrm{~g}, \mathrm{n}=30$ ) respectively. These average body weights are comparable with the averages reported by Green (1967) for northeastern Tasmanian quolls but lighter $(200 \mathrm{~g}$ for males and $100 \mathrm{~g}$ for females) than the average body weights reported for the species (Jones 2008). The survey timing (August) probably contributed to our light body weights. In winter Eastern Quoll body weights can be 16-31\% lighter than in summer (Jones \& Rose 2001). One male Eastern Quoll appeared to be in very poor condition; it had a high parasite load (ticks and fleas) and sparse fur and was skinny. It also had a thickened, raised, bare patch of skin on its abdomen. All but three females showed signs of having young or recently having had young. Half of the females (15/30) had pouch young, ranging in size and hairiness from about 10 $\mathrm{mm}$ and unfurred to about $45 \mathrm{~mm}$ and lightly furred and pigmented such that spots could be discerned. The number of pouch young ranged from 1-6 (average 4.4). The coat colour (light or dark) was recorded for 63 of the 68 quolls trapped. Sixty-two percent (39 animals) had light colour coats and this percentage was consistent regardless of sex (63\% for females and 61\% for males). This proportion of light colour coats is less than the proportion (75\%) reported by Jones \& Rose (2001).

\section{Brushtail Possum}

Brushtail Possums were recorded throughout "Murrayfield" using cage traps, cameras and spotlighting (tables 4-7). Large numbers of Brushtail Possums were seen while spotlighting on each of two nights in paddocks along Trumpeter Bay Road (table 7) and were considerably higher than those reported from annual statewide spotlight surveys $(<8$ per 10 $\mathrm{km}$ transect, Driessen \& Hocking 1992). These areas of the property have better quality pastures (B. Michael, Murrayfield Station, pers. comm.). Spotlight counts of possums were consistent between nights on the Trumpeter Bay Road transect but not for the grass tree track transect (table 7). It is not known why there was a difference on the grass tree track. Different observers may have contributed to this but counts of other animals were similar between the two nights. Relatively few Brushtail Possums were caught in cage traps and only at five of the ten locations (table 5). Hird (2000) did not trap any Brushtail Possums at Dennes Hill but noted that many were seen on roads. Our capture rates were similar to those found in E. tenuiramis forest and woodland in southeast Tasmania two years after a cool fire (Driessen et al. 1991). However, the captures rates recorded by Driessen et al. (1991) increased significantly four years later and they attributed this to vegetation changes following fire. Our Brushtail Possum capture rates were also similar to those reported from coastal heathlands and scrub of the Waterhouse Area (Driessen et al. 1995). Camera traps appeared to be more efficient than cage trapping in recording Brushtail Possums with detection at seven of the ten locations (table 6). Brushtail Possums were recorded in most vegetation types but were absent from $E$. 
TABLE 4

Number of mammals caught in cage traps at each location

\begin{tabular}{lccccccc}
\hline Location & Trap Nights & ECH & EQ & BP & LNP & Cat & BR \\
\hline Church Hill & 30 & 0 & $9(2)$ & 0 & 0 & 0 & 0 \\
Cockatoo Gully & 14 & 1 & $5(1)$ & 0 & 0 & 0 & 0 \\
Grass Tree/Pasture & 30 & 0 & $12(0)$ & 1 & 0 & 0 & 0 \\
Kirkby Creek & 18 & 0 & $6(1)$ & 2 & 0 & 0 & 0 \\
Lodge Hill & 30 & 0 & $7(3)$ & 4 & $4(0)$ & 0 & 1 \\
Roberts Hill & 45 & 0 & $14(3)$ & 0 & $5(1)$ & 0 & 0 \\
Saltmarsh & 30 & 0 & $9(0)$ & 1 & $1(0)$ & 1 & 0 \\
Shearing Quarters & 5 & 0 & $3(0)$ & 2 & 0 & 0 & 0 \\
Variety Bay & 30 & 0 & $14(2)$ & 0 & 0 & 0 & 0 \\
Yellow Bluff & 20 & 0 & $1(0)$ & 0 & 0 & 0 & 0 \\
Murrayfield & 5 & 0 & $0(0)$ & 0 & $2(0)$ & 0 & 0 \\
Total & 257 & 1 & $80(12)$ & 10 & $12(1)$ & 1 & 1 \\
\hline
\end{tabular}

Values $=$ captures + recaptures. Numbers in parentheses $=$ recaptures. $\mathrm{ECH}=$ Echidna, Tachyglossus aculeatus, $\mathrm{EQ}=$ eastern Quoll, Dasyurus viverrinus, BP = Brushtail Possum, Trichosurus vulpecula, LNP = Long-nosed Potoroo, Potorous tridactylus, Cat, Felis catus, BR = Black Rat, Rattus rattus

TABLE 5

Number of mammals caught in cage traps by vegetation type

\begin{tabular}{lccccccc}
\hline Vegetation Type & Trap Nights & ECH & EQ & BP & LNP & Cat & BR \\
\hline DAC & 45 & 0 & $14(0)$ & 2 & 1 & 1 & 0 \\
DGL & 18 & 0 & $6(1)$ & 2 & 0 & 0 & 0 \\
DOB & 11 & 0 & $4(1)$ & 0 & 2 & 0 & 0 \\
DOV & 8 & 0 & $5(1)$ & 0 & 0 & 0 & 0 \\
DPU & 101 & 1 & $22(6)$ & 4 & $9(1)$ & 0 & 1 \\
DTO & 54 & 0 & $19(3)$ & 0 & 0 & 0 & 0 \\
FAG & 20 & 0 & $10(0)$ & 2 & 0 & 0 & 0 \\
Total & 257 & 1 & $80(12)$ & 10 & $12(1)$ & 1 & 1 \\
\hline
\end{tabular}

Values = captures + recaptures. Numbers in parentheses = recaptures. ECH = Short-bealsed Echidna, Tachyglossus aculeatus, $\mathrm{EQ}=$ eastern Quoll, Dasyurus viverrinus, BP $=$ Brushtail Possum, Trichosurus vulpecula, LNP = Long-nosed Potoroo, Potorous tridactylus, Cat, Felis catus, BR = Black Rat, Rattus rattus. Vegetation codes: DAC = Eucalyptus amygdalina coastal forest and woodland, DGL $=E$. globulus dry forest and woodland, $\mathrm{DOB}=E$. obilqua dry forest, $\mathrm{DPU}=E$. pulchella forest and woodland, $\mathrm{DTO}=$ E. temuiramis forest and woodland on sediments, WGL $=E$. globulus wet forest, FAG $=$ agricultural land (pasture). ECH $=$ Short-beaked Echidna, Tachyglossus aculeatus, EQ = Eastern Quoll, Dasyurus viverrinus, $\mathrm{BP}=$ Brushtail Possum, Trichosurus vulpecula, $\mathrm{LNP}=$ Long-nosed Potoroo, Potorous tridactylus, $\mathrm{TP}=$ Tasmanian Pademelon, Thylogale billardierii, BW = Bennetts Wallaby, Macropus rufogriseus, BR = Black Rat, Rattus rattus.

TABLE 6

Mammal species detected $(x)$ by each of 10 camera traps

\begin{tabular}{|c|c|c|c|c|c|c|c|c|}
\hline Location & Veg. Type & $\mathrm{ECH}$ & $\mathrm{EQ}$ & $\mathrm{BP}$ & LNP & $\mathrm{TP}$ & BW & $\mathrm{BR}$ \\
\hline Church Hill & $\mathrm{DOB}$ & & $x(53)$ & $\mathrm{x}(24)$ & & $x(1)$ & $x(2)$ & $\mathrm{x}(2)$ \\
\hline Church Hill & DTO & $x(2)$ & $\mathrm{x}(12)$ & $\mathrm{x}(42)$ & $\mathrm{x}(1)$ & & $x(7)$ & \\
\hline Saltmarsh & DAC & & $\mathrm{x}(12)$ & $\mathrm{x}(10)$ & & $\mathrm{x}(\mathrm{I} 8)$ & & \\
\hline Grass Tree & $\mathrm{DAC}$ & $\mathrm{x}(4)$ & $x(29)$ & $\mathrm{x}(68)$ & $x(107)$ & $\mathrm{x}(9)$ & $x(2)$ & \\
\hline South of Church Hill & DTO & $\mathrm{x}(19)$ & & & $x(2)$ & & $\mathrm{x}(10)$ & \\
\hline Roberts Hill & DPU & & $x(22)$ & & $x(8)$ & & & \\
\hline Lodge Hill & DPU & & $\mathrm{x}(18)$ & $x(16)$ & $x(25)$ & & $x(12)$ & $\mathrm{x}(59)$ \\
\hline Roberts Hill & WGL & & $\mathrm{x}(7)$ & $\mathrm{x}(7)$ & & $\mathrm{x}(3)$ & $\mathrm{x}(9)$ & $\mathrm{x}(4)$ \\
\hline Kirkby Creek & $\mathrm{DGL} / \mathrm{FAG}$ & & $x(7)$ & & & & & \\
\hline Yellow Bluff & $\mathrm{DPU}$ & & & $\mathrm{x}(5)$ & $x(6)$ & & & \\
\hline Total locations & & 3 & 8 & 7 & 6 & 4 & 6 & 3 \\
\hline Total images & & 25 & 160 & 172 & 149 & 31 & 42 & 65 \\
\hline
\end{tabular}

Values in parentheses are the number of images taken of that species. Vegetation and species codes as for table 5. 
TABLE 7

Number of mammals recorded on spotlight survey transects

\begin{tabular}{|c|c|c|c|c|c|c|c|c|c|c|c|}
\hline Location & Date & $\begin{array}{c}\text { Distance } \\
(\mathrm{km})\end{array}$ & $\begin{array}{l}\text { Start } \\
\text { time }\end{array}$ & $\begin{array}{l}\text { End } \\
\text { time }\end{array}$ & $\mathrm{ECH}$ & $\mathrm{EQ}$ & $\mathrm{BP}$ & POT & $\mathrm{TP}$ & BW & $\mathrm{RAB}$ \\
\hline Variety Bay & $23 / 08 / 2010$ & 5.0 & 2113 & 2151 & 0 & 0 & 0 & 0 & 13 & 21 & 6 \\
\hline Grass Tree Track & $23 / 08 / 2010$ & 3.6 & 2110 & 2215 & 0 & 11 & 42 & 0 & 12 & 6 & 0 \\
\hline Yellow Bluff & $24 / 08 / 2010$ & 1 & 2020 & 2035 & 0 & 0 & 3 & 0 & 0 & 0 & 0 \\
\hline Lodge Hill & $24 / 08 / 2010$ & 1 & 2045 & 2100 & 0 & 0 & 3 & 0 & 0 & 0 & 0 \\
\hline Grass Tree Track & $24 / 08 / 2010$ & 3.6 & 2115 & 2200 & 0 & 7 & 14 & 0 & 19 & 7 & 0 \\
\hline Trumpeter Bay Road & $24 / 08 / 2010$ & 4.7 & 2013 & 2103 & 0 & 3 & 89 & 0 & 14 & 11 & 2 \\
\hline Trumpeter Bay Road & $25 / 08 / 2010$ & 4.8 & 2114 & 2201 & 0 & 2 & 100 & 1 & 10 & 12 & 2 \\
\hline Shortcut paddock & $25 / 08 / 2010$ & 1.8 & 2054 & 2108 & 1 & 2 & 2 & 0 & 0 & 0 & 0 \\
\hline Total & & 25.5 & & & 1 & 25 & 253 & 1 & 68 & 57 & 10 \\
\hline
\end{tabular}

Conditions during surveys were; no rain, cloudy, full moon and light or no wind. ECH = Short-beaked Echidna, Tachyglossus aculeatus, $\mathrm{EQ}=$ Eastern Quoll, Dasyurus viverrinus, $\mathrm{BP}=$ Brushtail Possum, Trichosurus vulpecula, LNP = Long-nosed Potoroo, Potorous tridactylus, $\mathrm{TP}=$ Tasmanian Pademelon, Thylogale billardierii, BW = Bennetts Wallaby, Macropus rufogrisetus, RAB = Rabbit, Oryctolagus cuniculus .

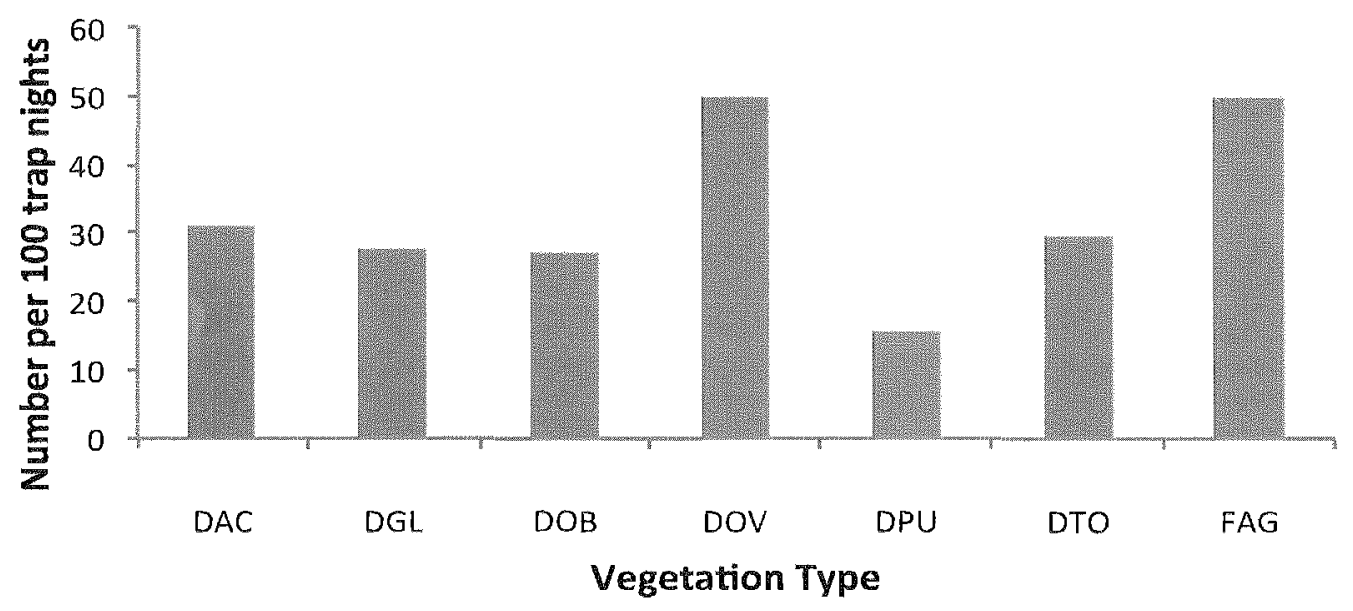

FIG. 2 - Rate of Eastern Quoll captures in cage traps in different vegetation types. Recaptures were not included. $D A C=$ Eucalyptus amygdalina coastal forest and woodland, $D G L=$ E. globulus $d r y$ forest and woodland, $D O B=\mathrm{E}$. obilqua dry forest, $D O V=\mathrm{E}$. ovata forest and woodland, $D P U=\mathrm{E}$. pulchella forest and woodland, $D T O=\mathrm{E}$. tenuiramis forest and woodland on sediments, $F A G=$ pasture.

tenuiramis forest and woodland perhaps suggesting that this species rarely uses this vegetation type which occur on nutrient-poor soils with low understorey species diversity (pl. 3) (Harris \& Kitchener 2005).

\section{Long-nosed Potoroo}

Long-nosed Potoroos, Potorous tridactylus (Kerr, 1792) were widely distributed across the property in areas with native vegetation cover (tables 4-7) and that had relatively dense ground cover as shown in plate 2 . They were mostly recorded using cage traps and cameras. We trapped 11 potoroos comprising five females and six males. All females carried pouch young that were small ( $<7 \mathrm{~cm}$ crown-rump length) and unfurred. Our traps success $(5 \%)$ was similar to that recorded in similarvegetation at Dennes Hill (8\%, Hird 2000) but considerably less than that recorded in $E$. amygdalina Labill. heathland (26\%, Driessen \& Jarman 2010). Despite the relatively large trapping effort in E. tenuiramis forest and woodland no potoroos were caught in this habitat. Although one image of a potoroo was caught on camera in this habitat, the results suggest that $E$. tenuiramis forest and woodland supports very low numbers of this species. A major habitat requirement for this species is relatively thick ground cover (Johnston 2008). Eucalyptus tenuiramis forest and woodland occurs on nutrient-poor soils and often has very sparse ground cover (Harris \& Kitchener 2005) as shown in plate 3. Only one potoroo was recorded while spotlighting which is consistent with low levels of detection during annual statewide spotlight surveys (Driessen \& Hocking 1992). 


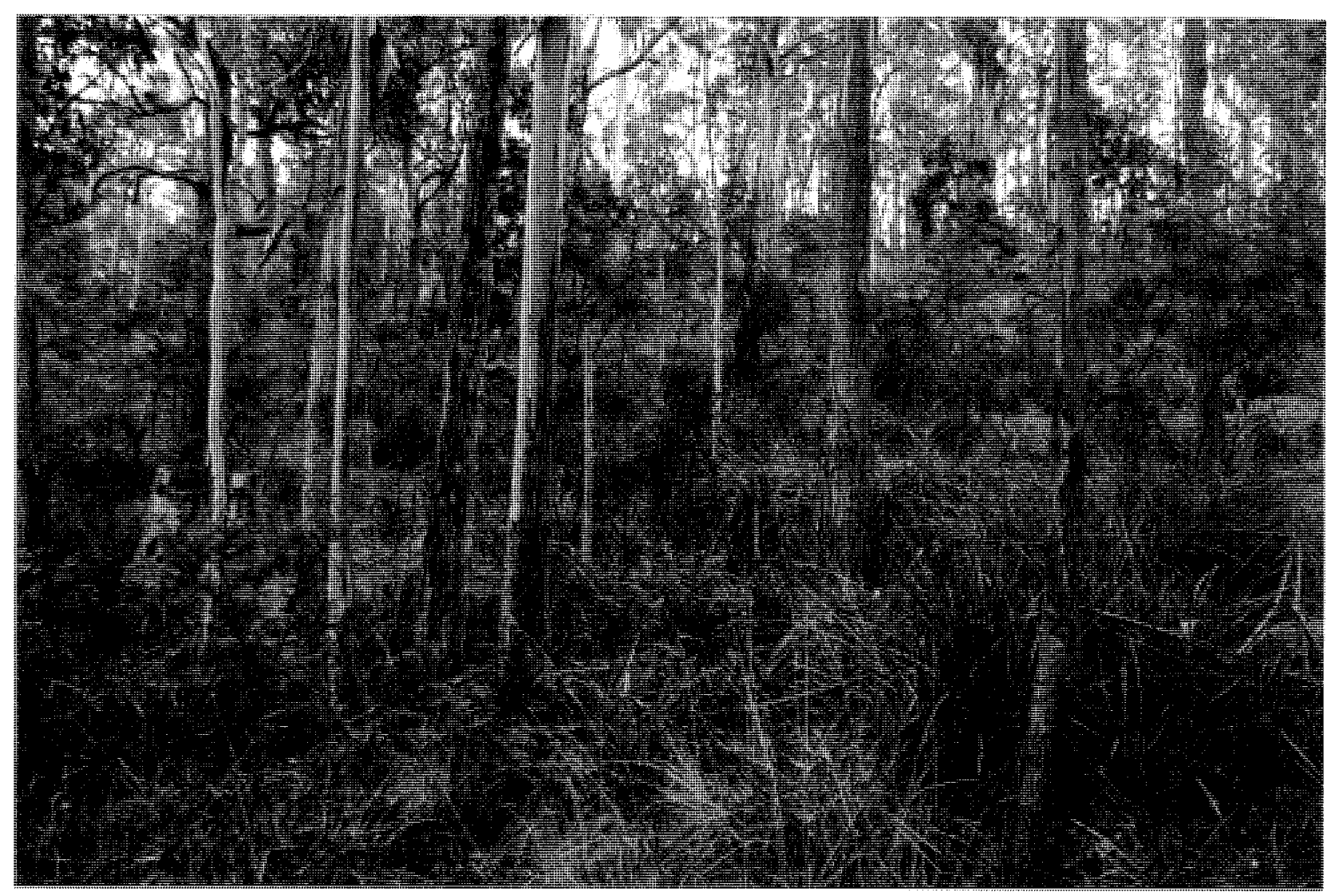

PLATE 2

Eucalyptus pulchella forest at Roberts Hill (Photo: M. Driessen).

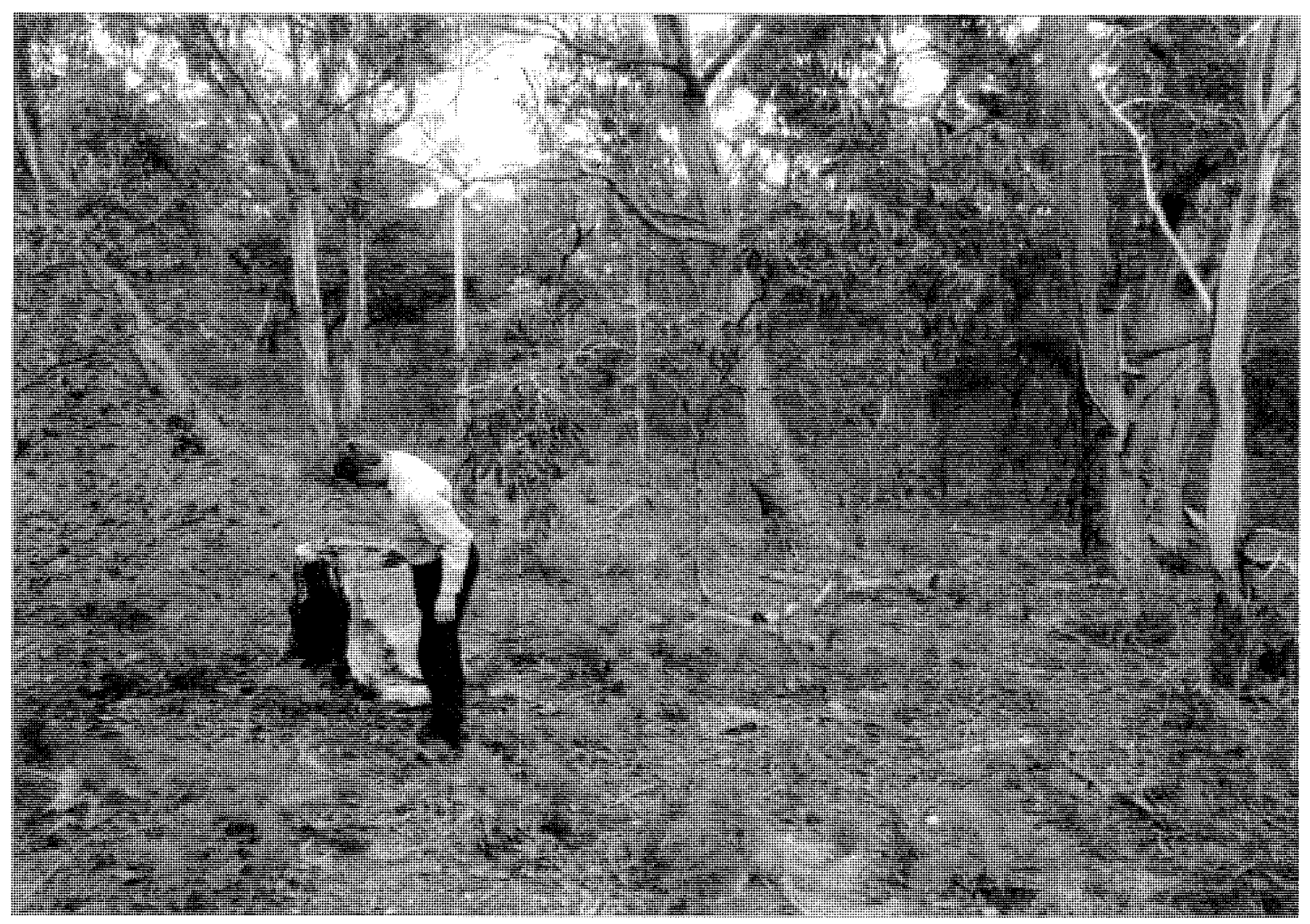

PLATE 3

Eucalyptus tenuiramis forest near Variety Bay (Photo: R. Gales). 


\section{Tasmanian Pademelon and Bennetts Wallaby}

The Tasmanian Pademelon and Bennetts Wallaby were primarily recorded by spotlighting and observing their scats and skulls (of shot animals). They were widely distributed and relatively abundant in pasture areas and were observed flecing into adjacent vegetation during spotlighting. The number of Tasmanian Pademelons (27) and Bennetts Wallaby (23) seen per ten kilometres is considerably higher than the average rate observed during annual statewide spotlight surveys between 1985 and 1990 (<10 animals per $10 \mathrm{~km}$, Driessen \& Hocking 1992) suggesting relatively large numbers of wallabies on the property. The large size of the wallabies precluded them from being caught in our cage traps (although small individuals are rarely caught). Camera traps recorded few images of Tasmanian Pademelons and at few locations. This species was not recorded on cameras in E. tenuiramis forest and woodland or E. pulchella forest and woodland. Camera traps also recorded few images of Bennetts Wallabies but they were recorded at more locations and in more habitats than the Tasmanian Pademelon. It is possible that the baits used to attract these two species to the cameras may not be effective.

\section{Eutherians}

\section{Little Forest Bat}

The time of the year and the weather conditions during the survey were not ideal for trapping and recording bats. Nevertheless, four Little Forest Bats-two adult males and two adult females- were caught in the harp trap. All bats were caught at the Saltmarsh location on the first night of survey which was before the cold change in weather occurred. Unfortunately, time constraints meant that the harp trap at Cockatoo Gully was not set until after the first night. We are not aware of any previous bat surveys on Bruny Island. A bat survey during warmer months is likely to increase the number of bats species detected on the property.

\section{Introduced species}

\section{Cat}

Only one Cat, Felis catus Linnaeus, 1758 was recorded during the survey. It was caught in a cage trap at the Saltmarsh location. No cats were recorded on camera or seen while spotlighting. Cats are rarely cage-trapped during mammal surveys in Tasmania despite evidence of their presence either by direct observation or by observation of sign (Hocking \& Guiler 1983, Taylor et al. 1985, Slater 1992, Driessen et al. 1995, Driessen \& Jarman 2010). Cats are also rarely observed on the annual statewide spotlight surveys with less than ten cats seen annually on the $13010-\mathrm{km}$ routes (Driessen \& Hocking 1992).

\section{European Rabbit}

Remarkably few European Rabbits, Oryctolagus cuniculus (Linnaeus, 1758) were observed on "Murrayfield". Ten rabbits were seen while spotlighting $(3.9$ per $10 \mathrm{~km})$ which is a little higher than the numbers observed annually during statewide spotlight surveys ( $<3$ per $10 \mathrm{~km}$ transect, Driessen \& Hocking 1992). Because our spotlight surveys were conducted in pasture areas we would have expected higher rabbit counts. The managers of "Murrayfield" reported that rabbit numbers were far greater on southern Bruny Island and speculated that Eastern Quolls may be limiting the growth of the rabbit population on northern Bruny Island.

\section{Black Rat}

Few Back Rats were recorded during the survey. Camera traps recorded them at three separate locations: in the gullies near Church Hill and Roberts Hill and in E. pulchella woodland on Lodge Hill. One was trapped in a cage trap on Lodge Hill. It is possible that with greater trapping effort around the shearing shed more might have been recorded. Black Rats have been rarely recorded in previous Tasmanian mammal surveys in native vegetation (Hocking \& Guiler 1983, Taylor et al. 1985, Slater 1992, Hocking \& Driessen 2000, Driessen et al. 2002) and most have been recorded in coastal vegetation (Slater 1992, Driessen et al. 1995).

\section{Species not recorded}

Several species of mammal were absent from this survey, and this is surprising given the suitability of the habitat present on "Murrayfield" and the large survey effort. The Southern Brown Bandicoot, Isoodon obesulus (Ramsay, 1887), Eastern Barred Bandicoot and Tasmanian Bettong have previously been recorded on Bruny Island (table 1) and all are readily caught in cage traps. The Southern Brown Bandicoot is often recorded where Long-nosed Potoroos occur and in pasture/native bush mosaics (Heinsohn 1966, Mallick et al. 1998, Driessen \& Jarman 2010). It was both surprising and pleasing that no introduced House Mice were recorded during the survey. This species is easily trapped in box traps. Limited survey effort was undertaken around the house and shed because of the presence of domestic Dogs, Canis lupus familiaris Linnaeus, 1758, and it is likely that House Mice occur in these areas from time to time. Probable mouse footprints were observed in fat on a barbeque at the shearing quarters. Most of "Murrayfield" is probably unsuitable for the native Swamp Rat, which occurs in wetter vegetation types and coastal heathlands (Hocking \& Driessen 2000), but we thought that Swamp Rats might be recorded in vegetation adjacent to drainage lines. No Water Rats, Hydromys chrysogaster Geoffroy, 1804, were observed but the managers of "Murrayfield" advised that Water Rats have been seen at the mouth of Kirkby Creek (B. Michael, Murrayfield Station, pers. comm.). PWS rangers have also trapped a number of Water Rats at The Neck (B. Edwards, Parks and Wildlife Service, pers. comm.). Hird (2000) observed footprints of Water Rats on the coast near "Lauriston". No Common Ringtail Possums Pseudocheirus peregrinus (Boddaert, 1785) were recorded but the methods used did not specifically target this arboreal species. However, there was potential to observe their dreys or to spotlight them in trees. Hird (2000) observed a group of three Common Ringtail Possums crossing a road on northern Bruny Island in 1996.

\section{Comparison of mammal survey methods}

There are few studies that compare the effectiveness of survey techniques to detect mammals in Australia. Camera trapping is increasingly being used as a method for surveying mammals; however, there have been few studies comparing their effectiveness in surveying Australian mammals with other methods (De Bondi et al. 2010). Although our study was not specifically designed to compare survey methods some general comments are warranted as they may assist with the planning of future mammal surveys in Tasmania. 
We found that Eastern Quolls and Brushtail Possums were widely recorded using camera trapping, cage traps and spotlighting. Whether similar levels of detection would be obtained at lower densities requires further investigation. In general, camera trapping and cage traps were similar in their ability to detect Long-nosed Potoroos. Where the two methods were used in similar locations, the cameras recorded potoroos at two locations where they were not trapped and cage trapping recorded potoroos at one location where they were not camera trapped. Spotlighting was not an effective way to monitor potoroos with only one individual observed and this is consistent with other spotlight surveys in areas where Long-nosed Potoroos occur (Driessen \& Hocking 1992). Few pademelons were recorded on camera traps suggesting this method may not be effective for this species. Cameras were more effective at detecting Bennetts Wallabies than Tasmanian Pademelons but the low number of images recorded compared with other species also suggests that cameras or the baits used are not effective for detecting this species. Spotlighting appeared to be more effective in detecting both these macropods than cameras at least in the pasture and forest mosaic on "Murrayfield". It is possible that cameras may be more effective in large expanses of native vegetation in detecting these species. The only species caught in cage traps that was not recorded on cameras was the Cat which was recorded at the Saltmarsh where a camera was also located. Rabbits were only recorded by spotlighting.

A previous study has found that camera trapping is more cost-effective than live trapping terrestrial small mammal communities in Victoria, Australia (De Bondi et al. 2010). Although we did not calculate the resources used to undertake the different survey methods during our survey, it is clear that camera trapping is a more cost-effective survey technique than live trapping for detection of mammals on "Murrayfield". It is worth noting, however, that due to inherent difficulties in identifying individual animals from images, this technique is limited to providing information on presence/absence rather than abundance. Whether camera trapping is more efficient than spotlighting in detecting mammals will require further investigation but spotlighting failed to record Black Rats and is not effective in recording Potoroos and Short-beaked Echidnas.

\section{MANAGEMENT CONSIDERATIONS}

Key issues for the management and conservation of native terrestrial mammals include: vegetation clearance, degradation and fragmentation; introduced species; inappropriate fire regimes; unsustainable hunting; and disease.

One of the aims for the property is to balance the demands of running an established sheep and fine merino wool business with protecting cultural and environmental values. Large areas of "Murrayfield" have been cleared for pasture resulting in a mosaic of forest, woodland and pasture. This mosaic can benefit a number of native mammal species by providing increased food resources in the pasture (grasses and invertebrates) adjacent to shelter in the forest and woodland. This may be why Brushtail Possums, Tasmanian Pademelons, Bennetts Wallabies and Eastern Quolls were found to be abundant and widespread on the property. Two further species, the Southern Brown Bandicoot and in particular the Eastern Barred Bandicoot, can also benefit from the pasture/bush mosaic but were not recorded during the survey. Both species are easily detected by the methods used during the survey. Conditions on "Murrayfield" may be marginal for the Eastern Barred Bandicoot which are more common in high-quality agricultural land with deep soils and high rainfall (Driessen et al. 1996). Numbers of Eastern Barred Bandicoot are thought to be influenced by rainfall (Heinsohn 1966, Mallick et al. 2000) and the extended dry conditions on the island prior to the survey may have contributed to a lack of observations. It is also possible that the very high numbers of quolls are contributing to the absence of bandicoots. Eastern Quolls and bandicoots compete for the same food resources (invertebrates) and quolls may also prey upon bandicoots.

Although a number of native mammal species can benefit from a pasture/bush mosaic, many others require, or are restricted to, areas of native vegetation cover. "Murrayfield" retains large areas of native forest and woodland but some of the value of this habitat for native mammals has been degraded through unrestricted sheep grazing and clearing of undergrowth. Species recorded on "Murrayfield", or which have potential to be recorded, and are largely restricted to native vegetation are the Long-nosed Potoroo, Tasmanian Bettong and Swamp Rat. We recorded Long-nosed Potoroos at several locations on "Murrayfield" that, from casual observation (also see pl. 2), had limited grazing pressure and retained good levels of cover (e.g., Roberts Hill, Saltmarsh, Lodge Hill, Murrayfield). It would be reasonable to assume that other parts of the property supporting stands of $E$. amygdalina, E. pulchella and E. obliqua L'Hérit forest and woodland could support Long-nosed Potoroos if protected from grazing.

The lack of recorded Tasmanian Bettongs during the survey is puzzling because much of the forest and woodland on the Murrayfield property is consistent with typical habitat for this species (Driessen \& Hocking 1990). The species is easily trapped and observed by spotlighting. The last official record of a Tasmanian Bettong on northern Bruny was in March 1974 by Hans and Annie Wapstra (Natural Values Atlas record). An animal resembling a bettong was caught during cat trapping near the homestead on "Murrayfield" early in 2010 (L. Michaels pers. comm., Murrayfield Station). Drought and limited firing of vegetation may be factors contributing to the absence of bettongs. The Murrayfield Native Vegetation Management Plan noted that (as of January 2005) there was little evidence of fires in the past 10 years. During our mammal survey in August 2010 we also noted little evidence of fires. There have not been any major wildfires on "Murrayfield" for at least 40 years (Murrayfield Fire Management Plan Draft 2008) and there has been no hazard-reduction or ecological burning on "Murrayfield" since it was acquired by the Indigenous Land Corporation in 2001. There is some evidence that bettongs can benefit from firing some vegetation types provided it does not occur too frequently (Johnson 1995, 1997). Fire can promote production of fruiting bodies of some subterranean fungi, the main food for this species (Johnson 1995). However, it is difficult to determine whether lack of firing is related to the apparent absence of this species on the property. The fire frequencies recommended for different vegetation communities on "Murrayfield" in the Murrayfield Native Vegetation Management Plan should be implemented to determine if it will benefit bettongs.

Swamp Rats require native vegetation cover with dense ground cover and primarily occur in wet forests, moorland and coastal heathland, but they also occur along drainage lines in drier parts of Tasmania (Hocking \& Dreissen 
2000). Suitable habitat for this species is very limited on the property although it would be reasonable to expect the species to occur along some of the drainage lines where there is a dense cover of cutting grass, Gahnia grandis (Labill.). Some creek lines have been cleared of vegetation that might have supported this species. We recommend excluding fire (and grazing) from riparian vegetation as also recommended in the Murrayfield Native Vegetation Management Plan.

Remarkably few introduced mammals were recorded during the survey. Black Rats were recorded in native vegetation at various locations on the property. There is little evidence to suggest that this species, although undesirable, displaces native rodents such as Swamp Rats. Remarkably, no House Mice, which are easily caught in box traps, were caught during the survey. It is possible that greater trapping effort around the shearing shed and houses would have resulted in captures of House Mice and more Black Rats. Workers on "Murrayfield" have observed and controlled cats and one cat was trapped during the survey at the Saltmarsh. Cats prey on native mammals but their impact on Tasmanian mammals has not been quantified. It could be argued that on an island with limited habitat cats may pose a greater threat to native mammal populations than on mainland Tasmania and perhaps they could be contributing, along with other factors, to the absence of species such as bandicoots and bettongs. Cats are the definitive host for the disease toxoplasmosis which can lead to death in native species particularly bandicoots (Obendorf et al. 1996). Although cats and bandicoots readily co-exist in Tasmanian mainland communities, it could be argued that the small populations on northern Bruny are at greater risk from toxoplasmosis.

Wallabies and possums are culled on the property to reduce their competition for food with sheep. There is no evidence to suggest that the current culling level is not sustainable. Controlling numbers of wallabies and possums should prevent build-up of large populations and high levels of grazing impacts on the native vegetation, as has occurred on Maria Island.

\section{RECOMMENDATIONS}

Management of mammals on "Murrayfield" primarily involves maintaining existing native vegetation and control of introduced animals. The Murrayfield Native Vegetation Management Plan divides the property into 11 management zones and provides detailed advice on managing vegetation as well as threatened fauna. In particular it identifies areas that should be fenced from stock, and fire regimes to be implemented for different vegetation types. Continued implementation of the vegetation management plan will be beneficial for the management of mammals on the property. In summary, it is recommended that:

- the Murrayfield Vegetation Management Plan continues to be implemented;

- the fire management plan be implemented;

- further areas of creek lines be protected from grazing;

- areas be identified, planted and fenced-off to increase connectivity between larger native habitat patches;

- cats continue to be controlled;

- surveys for bats be undertaken;

- monitoring of mammals be undertaken every five years;

- deadwood be maintained in native vegetation for nesting hollows for mammals;
- a register be kept of mammal observations, particularly of less common species; and

- fox sightings be reported.

\section{ACKNOWLEDGEMENTS}

This survey was funded by the Indigenous Land Corporation and the Tasmania Government. We thank Bruce and Lynne Michael for their hospitality, assistance with the survey and their advice on mammals on the property. Thanks also go to Michael Pemberton, Margaret Horton and in particular Bronwyn Fancourt for their assistance with the survey. This survey was undertaken with Animal Ethics Committee approval (DPIPWE AEC Number 1/2010-11) and with permits to take protected wildlife and threatened species issued to all authors. We also thank an anonymous reviewer for helpful comments and for improving the scope of the manuscript.

\section{REFERENCES}

Cochran, T. 2003: Managing Threatened Species \& Communities on Bruny Island. Threatened Species Unit, Department of Primary Industries, Water and Environment, Tasmania: $58 \mathrm{pp}$.

De Bondi, N., White, J.G., Stevens, M. \& Cooke, R. 2010: A comparison of the effectiveness of camera trapping and live trapping for sampling terrestrial small-mammal communities. Wildlife Research 37: 456-465.

DPIPWE 2011: Latest Physical Evidence of Foxes in Tasmania. Department of Primary Industries, Parks, Water and Environment, 'Tasmania. http:/www.dpiw.tas.gov.au/ inter.nsf/WebPages/LJEM-6SH7FX?open (accessed 10 March 2011).

Driessen, M.M., Brereton, R. \& Pauza, M. 2011: Status and conservation of bats in Tasmania. In B. Law, P. Eby, D. Lunny \& L. Lumsden (eds): The Biology and Conservation of Australiasian Bats. Royal Zoological Society of NSW, Mosman, NSW, Australia. 324-336.

Driessen, M.M. \& Hocking, G.J. 1990: The habitat and conservation status of the Tasmanian bettong. Tasmanian Naturalist 102: 1-6.

Driessen, M.M. \& Hocking, G.J. 1992: Review and Analysis of Spotlight Surveys in Tasmania: 1975-1990. Department of Parks, Wildlife and Heritage Scientific Report 92/1, Hobart: 65 pp.

Driessen, M.M., Hocking, G.J. \& Holdsworth, M.C. 1995: Mammals of the Waterhouse Protected Area. In M.C. Holdsworth \& S. Bryant (eds): A Biological Survey of the Waterhouse Area, Northeast Tasmania. Wildlife Branch Scientifc Report No. 95/5, Hobart: 15-21.

Driessen, M.M. \& Jarman, P. 2010: The response of mammal populations to fire in the Peter Murrell reserves: initial survey. Tasmanian Naturalist 132: 96-100.

Driessen, M.M., Mallick, S.A. \& Hocking, G.J. 1996: Habitat of the eastern Barred Bandicoot, perameles gunnii, in Tasmania: an analysis of road-kills. Wildlife Research 23 : $721-727$.

Driessen, M.M., Pigott, K. \& Reid, T. 2002: Small mammal habitat use in buttongrass moorlands, Tyndall Range, western Tasmania. Tasmanian Naturalist 124: 38-48.

Driessen, M.M., Taylor, R.J. \& Hocking, G.J. 1991: Trends in abundance of three marsupial species after fire. Australian Mammalogy 14: 121-124.

Green, R.H. 1967: Notes on the devil (Sarcophilus harrisii) and the quoll (Dasyurus viverrinus) in north-eastern Tasmania. Records of the Queen Victoria Museum 27: 1-13. 
Green, R.H. 1973: The Mammals of Tasmania. The author, Launceston: $76 \mathrm{pp}$.

Green, R.H. 1977: The vertebrate fauna of Maggs Mountain, Tasmania. Records of the Queen Victoria Museum 58: 1-40.

Green, R.H. 1979: A survey of the vertebrate fauna of a heathland area between Round Hill and the Gardens, north-east Tasmana. Records of the Queen Victoria Museum 67: 1-11.

Green, R.H. 1984: The vegetation, fauna and archaeology of Ordnance Point, north-western Tasmania. Records of the Queen Victoria Museum 84: 1-35.

Harris, S. \& Kitchener, A. 2005: From Forest to Fjaeldmark: Descriptions of Tasmania's Vegetation. Department of Primary Industries, Water and Environment, Printing Authority of Tasmania, Hobart.

Heinsohn, G.E. 1966: Ecology and reproduction of the Tasmanian bandicoots (Perameles gunnii and Isoodon obesulus). University of California Publications in Zoology 80: 1-107.

Hird, D. 2000: Terrestrial mammals of Dennes Hill, North Bruny Island. Tasmanian Naturalist 122: 9-14.

Hird, D. 2009: Pygmy possum excursion to Bruny Is - 8 Feb 2009. Tasmanian Field Naturalists Chub Inc. Bulletin 334: 3-4.

Hocking, G.J. \& Driessen, M.M. 2000: Status and conservation of the rodents of Tasmania. Wildlife Research 27: 371-377.

Hocking, G.J. \& Guiler, E.R. 1983: The mammals of the Lower Gordon River region, south-west Tasmania. Australian Wildlife Research 10: 1-23.

Hope, J.H. 1972: Mammals of the Bass Strait Islands. Proceedings of the Royal Society of Victoria 85: 163-195.

ILC 2009: Murrayfield Station, Bruny Island: Balancing productivity with protection. www.murrayfield.com.au. (accessed 1 September 2011).

Johnson, C.N. 1995: Relationship between fire, mycophagous mammals and dispersal of ectomycorrhizal fungi in Eucalyptus forests. Oecologia 104: 467-475.

Johnson, C.N. 1997: Fire and habitat management for a mycophagus marsupial, the Tasmanian bettong Bettongia gaimardi. Australian Journal of Ecology 22: 101-105.

Johnson, K.A. \& Rose, R.W. 2008: Tasmanian Pademelon. In S. Van Dyck \& R. Strahan (eds): The Mammals of Australia. Reed New Holland, Sydney: 395-397.

Johnston, P.G. 2008: Long-nosed Potoroo. In S. Van Dyck \&R. Strahan (eds): The Mammals of Australia. Reed New Holland, Sydney: 302-304.
Jones, M. 2008: Eastern Quoll. In S. Van Dyck \&R. Strahan (eds): The Mammals of Australia. Reed New Holland, Sydney: 62-64.

Jones, M.E. \& Rose, R.K. 2001: Dasyurus viverrinus. Mammalian Species 677: 1-9.

Lloyd, S. 2009: The Birds at Murrayfeld. The Author (Birds Tasmania): $40 \mathrm{pp}$.

Mallick, S.A., Driessen, M.M. \& Hocking, G.J. 1998: Biology of the southern brown bandicoot (Isoodon obesulus) in south-eastern Tasmania. II. Demography. Australian Mammalogy 33: 339-347.

Mallick, S.A., Driessen, M.M. \& Hocking, G.J. 2000: Demography and home range of the eastern barred bandicoot (Perameles gunnii) in south-eastern Tasmania. Wildlife Research 27: 103-115.

Obendorf, D., Statham, P. \& Driessen, M. 1996: Detection of agglutinating antibodies to Toxoplasma gondii in sera from free-ranging eastern barred bandicoots (Perameles gunnii). Journal of Wildlife Diseases 32: 623-626.

Pemberton, M. 2004: The geology, geomorpholgy and landscape cvolution of Murrayfield, Bruny Island and adjacent areas. Nature Conservation Report 04/1: 1-13.

Rounsevell, D.E., Taylor, R.J. \& Hocking, G.J. 1991: Distribution records of native terrestrial mammals in Tasmania. Wildlife Research 18: 699-718.

Sherriff, L. \& Magnus, Z. 2005: Murrayfeld Native Vegetation Management Plan 2005-2014. Nature Conservation Branch, Department of Primary Industries, Water and Environment: $116 \mathrm{pp}$.

Slater, J. 1992: Vertebrates. In D.N. Harries (ed.): Forgotton Wilderness: North West Tasmania. Tasmanian Conservation Trust inc., Hobart: 251-289.

Taylor, R.J., Bryant, S.L., Pemberton, D. \& Norton, T.W. 1985 : Mammals of the Upper Henty River region, Western Tasmania. Papers and Proceedings of the Royal Society of Tasmania 119: 7-14.

Woinarski, J. 1985: Sharing of small hollow by roosting bats and nesting forty-spotted pardalotes. Tasmanian Naturalist 84: 1 .

Ziegeler, D. 1971: 1971 Easter Camp - Denne's Point. The Tasmanian Naturalist 26: 1 .

(accepted 8 November 2011) 